\title{
An Ethnographic Look at Informing and Transforming Schools
}

\author{
Lucia Buttaro \\ Adelphi University, New York, USA
}

\begin{abstract}
The present study, which is the focus of "Words on the Wet Paper" emerged from work with families in a variety of settings and contexts. Interactions with these families as part of the author's work with the children often reveal circumstances surrounding immigration. The teachers were invited to for a Collaborative Learning Community for English Language Learners and met once a month to delve into research on second language learners and crafted instructional strategies based on the variety of scholarly sources which were piloted in the classroom. Two of the strategies were identified as being particularly successful with the students: (1) reciprocal teaching to model and scaffold the use of comprehension strategies and (2) the use of cognates in vocabulary instruction.
\end{abstract}

Keywords: ethnography, bilingual education, immigration, ethnic minorities, No Child Left Behind, field work, literacy, home visits, cognates, persuasive discourse

"When I write I feel more better after I put the words, you know on the wet paper”. -Silvia, Honduran immigrant,

Field notes, May 20, 2007

\section{Introduction}

Silvia's words were spoken during an interview that was part of a research project in East Harlem. This portrayal of the impact of articulating critical aspects of her immigrant experience through literacy became a central focus of a study which subsequently bore the title, "Words on the Wet Paper: Exploring the Lives and Literacies of Immigrant Families”. The purpose of this ethnographic study was to document the literacy practices of Latino immigrant families. What occurred in the wake of the author's time in the field however altered her role as a facilitator, researcher and professional staff developer and served as a catalyst for change in the bilingual magnet school where she offered professional development. It has illustrated an important point. Research located in the community and conducted by teachers hopefully has the capacity to inform and thereby transform the work done in schools. This occurs when ethnographic data, much like the following exchange with Silvia, is collected, analyzed, and considered for its possible impact on the system of school and instructional practices.

The moment Silvia uttered the words, "When I write, I feel more better after (I) put the words, you know, on the wet paper" will always be remembered. The author was sitting across the table from Silvia as she read a poem written for her mother years before. Both sets of eyes were wet with tears as Silvia expressed the profound sense of loss felt by a daughter who was separated through time and space by the difficult choice to emigrate. The poem is entitled: "Desde la Distancia..." which means, "From the Distance..." The final stanza from this poem

Lucia Buttaro, professor, Ph.D., Department of Curriculum and Instruction, Adelphi University. 
translated from the original Spanish text reads:

\author{
I have to write these lines \\ Everybody will be a witness \\ To a mother's love to a child \\ That time or the distance could not destroy it, never, ever. (Romberg, 1996, p. 18)
}

Silvia, an immigrant from Honduras, shared this poem during one of many data-gathering meetings. As she does so, she provides an intimate glimpse into the importance of the literacy practices intimately connected to the immigrant experience. Her words reflect the importance of a main focus of this ethnographic study. Literacy is often seen as a means by which people can navigate and negotiate aspects of their lives. The notebook in which she writes is an artifact and it provides documentation of the multiple ways in which literacy is intertwined with the unique experience of immigration. Silvia's "wet paper" symbolizes the use of literacy as a means to make sense of the painful realities with which many immigrants must come to terms. Through Silvia's writing, the importance of this study is encapsulated in this simple image of a woman writing on paper wet with tears.

\title{
What Is Ethnography?
}

In an effort to explore these issues, this study relied on ethnography as a research tool. Ethnography is intended to describe the collective behavior of a group of people accompanied by analysis and interpretation (August \& Shanahan, 2006). Sonia Nieto (1996) speaks of the value of ethnography in the educational setting noting that "This kind of research can lead to a better understanding of the educational process in multicultural settings because it has numerous implications for policies and practices in schools” (p. 138). It is through this ethnographic documentation of the details of the literacy practices connected to the everyday life of courageous immigrants like Silvia that the power of ethnography is revealed. This form of research may be viewed as a critical ethnography, or one that focuses on "the way affluent interests oppress ordinary folks" (Agar, 1996. p. 29). Through ethnography, the authors may learn of the significance of the literacy practices of the families in this study and the ways in which these practices are a part of the social fabric of everyday life. In so doing, this type of work may serve to change often held perceptions of non-mainstream groups with the hopes that "new sensitivities replace old stereotypes” (August \& Shanahan, 2006, p. 195).

It was expected that through ethnography, the researcher would come to better know the families of the school community. What she did not expect, however, was the impact that sharing data from the study, in both formal and informal ways, would impact the work conducted in her role as a professional staff developer. Both the evolution and influence of this ethnographic research is conceptualized in the graph in Figure 1. The left side of the graph represents the factors that guided the research towards ethnography. The center of the graph represents the time spent in the field during data collection and the right side of the graph illustrates the influence the study has had on the author's work in school. In short, through research which informs teachers about the lives of students outside of school and makes known the experiences and resources they bring to their learning, there is the capacity to transform the work conducted in schools. This occurs by altering the affective domain, in both the ways in which teachers view children and families, and the ways children and families experience school that, in turn, creates the possibility of developing curriculum that paves the path for achievement for not just English Language Learners, but for all students. 
The act of documenting the lives and literacies of immigrant families is important for several reasons. Many schools struggle to provide children from poor and diverse communities the type of program that enables them to compete with the more affluent peers. This is evident in the disproportionate number of students of color who are unable to achieve academically in school. This phenomenon, commonly referred to as the achievement gap (Berlak, 2001), addresses this failure on the part of schools and is mirrored in some staggering statistics, not the least of which is that of all ethnic groups, Latinos have the highest rate (Edwards, 2006). The achievement levels during the time of this study as reported in the New York State School Report are a harbinger of that dismal phenomenon.

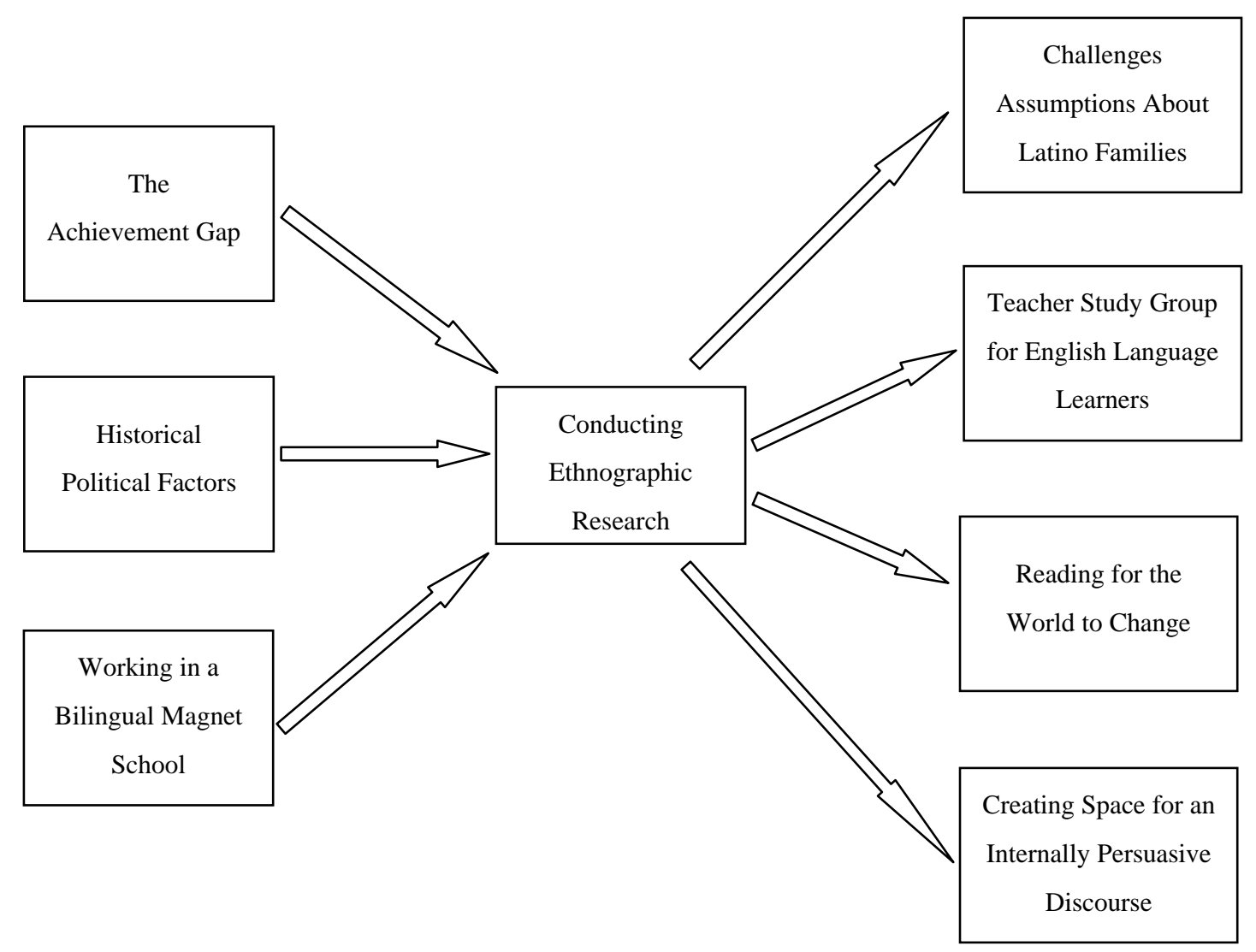

Figure 1. Ethnographic influence and research.

The 2006-2007 New York State School Report:

\author{
91\% of students eligible for free or reduced lunch \\ $7 \%$ of the student body is white \\ 59\% of students labeled Limited English Proficient \\ $35 \%$ of students passed 4th Grade English Language Arts Exam \\ Of the students labeled as Limited English Proficient, only 23\% passed
}

Certainly this disturbing data demonstrates the need to search for reasons this would occur and ways to address it. Ethnography may be viewed as a way to approach this problem through research. It seems incumbent on those who witness inequities in education firsthand to conduct inquiries that search for answers and alternatives. For this study, the beginning premise was that it would be important to understand the ways in which 
literacy is embedded in the lives of groups of people who may be disenfranchised. This creates the possibility to develop curriculum in much the same way as Gerald Campano (2007) shared his work, Reading, Writing and Remembering. In this study, he shares the many ways "Literacy became one means of recuperating cultural competencies, traditions and residual cultural values that would enable students to adapt and succeed in school” (Campano, 2007, p. 114). For children of immigration, the type of knowledge gained through ethnography may very well be an untapped resource that has the potential to close gaps in achievement.

\section{Historical and Political Significance}

A look at the demographics of the population reveals that the United States is experiencing the largest wave of immigration in the history of the USA. By the year 2050, 50\% of the population will be made up of "ethnic minorities" and by that same year, fully one quarter of all people residing in this country will be of Latino origin (C. Suarez-Orozco, Todorova, \& Louie, 2002). There are 10.5 million children of immigrants in U.S. schools, one quarter of these students is foreign born and three quarters are born in this country. This accounts for one in five of the students in kindergarten through 12th grade (Fix \& Passel, 2003). The number of people speaking a language other than English increased from 23 million (11\%) in 1980 to almost 32 million (14\%) in 1990 and continues to grow (Nieto, 1996). Beyond school walls, issues concerning immigration are ever present. The brutal murder of Marcelo Lucero shocked the local community as well as the nation. In what has been described as a hate crime, this New York resident of Ecuadorian descent was attacked by seven teenagers.

The growth in the number of Latino immigrants entering the country is coupled with the enactment of the No Child Left Behind Act of 2001. This federal legislation professes to be "An act to close the achievement with accountability, flexibility, and choice, so that no child is left behind” (Pub. L. No 107-110). In theory, this appears to be a worthwhile goal for all children; however, the reality is that there are serious repercussions for children of immigration. First, the law has clear expectations "for immigrant children and youth" that requires among other things "demonstrated improvements in the English proficiency of limited English proficient children each fiscal year” (Pub. L. No 107-110 S 3102, 115 Stat. 1690). The emphasis throughout this portion of the law is clearly on the acquisition of English, disregarding a body of research on second language acquisition that has "demonstrated that students can learn through their native language while learning English and also achieving academically” (Glendon, 2006, p. 25).

\section{The Ethnographic Study}

Agar (1996) states, "without science, we lose our credibility. Without humanity, we lose our ability to understand others” (p. 65). Ethnographic research provides a means to engage in educational research through the lens of the human experience. With this goal in mind and inspired by the promise of capitalizing on the Funds of Knowledge students possess (Gonzalez, Moll, \& Amanti, 2005), this study was located in the community for the purpose of learning something of the lives and literacies of the families of the children who attend the school and to consider the ways in which this knowledge may influence the work conducted in the school.

Over the course of the field work, the author spent time with many families. Five emerged as a focus of this study. The names of the members of each family have been changed to ensure their anonymity which is a common practice to protect the identities of study participants. In this case, it is important to emphasize the fact 
that parents who may not possess legal status, and/or who were not fluent speakers of English, invited the author, a professor who has lived, worked and studied in Buenos Aires, Argentina, for 10 years into their lives and into their literacies. This act alone is a testament to the commitment these families have to the education of their children. They live in the community surrounding the school where the author offered professional development.

(1) The Ramirez family came here from Ecuador. The mother, Marlene is a school bus driver and her husband Pedro is a truck driver. Their children, Miguel and Marissa, attended the school and the researcher worked with them when they were in first and third grades, respectively.

(2) The Sanchez family is from the Dominican Republic. The mother, Isabella, lives in a small house with her father, her three sons and a nephew. Two of the boys, Juan and Jose were students at the school. Juan was in the fourth grade during field work while Jose was a student when he was in first and second grade. Her husband, Jairo, spent the duration of their marriage in the Dominican Republic. The family has spent their summers there with him.

(3) The Perez family also comes from Ecuador. Marta is a teacher's aide in the school who lives with her husband Roberto and their two daughters, Liliana, and Carla, in a neighboring town which also is the home of a large Latino population. The girls, in grades four and six during field work, were described to the researcher primarily through the words of their mother.

(4) Katherine and Ronaldo Rios are immigrants from Colombia. Their children, Ronaldo, Jr. and Gilberto, are also students at the school. Upon first meeting Ronaldo, he was in the first grade and Gilberto was in preschool. Currently, they are in the fourth and second grades.

(5) The Cortez family is from El Salvador. The father, Miguel was the first to arrive in the United States. Several years later, he was followed by his wife Rosanna. The oldest sons, Felix and Jorge, were the next to arrive and were in high school during the time of the field work. The youngest members of the family, Antonio in second grade and Leonardo in kindergarten, were born in the United States. One child, Lydia, who was 11, remains in El Salvador with her grandmother.

Field work consisted of the time spent with the families both at home and in school. Interviews were open in nature; however, the broad array of topics discussed fall under four main themes. These are: (1) Coming to the United States, (2) Everyday Life, (3) The Children in School, and (4) Hopes for the Future. The conversations the researcher had surrounding these topics with each family affected her in profound ways. First, all the participants shared aspects of their lives that were both fascinating and moving, yet rarely recognized in school. Also, it was obvious that literacy was embroidered through all aspects of their everyday life. It was soon realized that these literacy practices which supported the familiars in both practical and profound ways could be avenues for understanding and thereby a means to inform the development of curricula in schools.

\section{Findings and Implications}

In Pedagogy of the Oppressed, Freire (1970) makes a critical point about a form of dialogue that is essential to the ethnographic process. He states, "It is not our role to speak to the people about our own view of the world, nor to attempt to impose that view on them, but rather to dialogue with the people about their view and ours" (Freire, 1970, p. 77). Through research situated in the community, the voices of the families may be heard in the schools. These voices represent a means to develop understandings of the lives of the students and all that brings 
to the educational experience. Some of these understandings are represented in a brief discussion of the main findings of the study and the implications these findings have for schools.

Silvia's "words on wet paper" is a metaphor for a main finding of this study: Literacy is a tool and a resource from which immigrant families draw to support themselves through this experience. Silvia's metaphor describes the uses of literacy for many who are immigrants and their struggle to make sense of the poignant realities that are embedded in this experience. It reveals the emotional toll for daughters like Marta, who leave behind their loved ones in the hopes of a better life. It is also a metaphor for mothers who come to the United States and must leave children behind and for those who have children here and for all families separated by miles and the bureaucratic and political texts of immigration policies. It represents the struggles of mothers and fathers who send their children to American schools as they strive to work and build a new life for their families.

Literacy, in its many forms, supported the families in both ordinary and extraordinary ways. Silvia's poetry and prose illustrates the ways she drew on literacy to content with her profound sense of loss. Other families soothed the ache they felt for home in more everyday endeavors. Marlene and Pedro found great comfort reading the monthly periodical Vistazo that her mother sends from Ecuador. They also regularly read the Spanish language newspaper $\mathrm{La}$ Voz and enjoyed Spanish television programs. Through these forms of print and visual media, they not only were able to read and hear the familiar sounds of their native language, but they were able to keep informed about the news from home.

For Catherine, the ways she experienced her identity as a woman as a result of her immigration caused her to draw from literature to make sense of this changing role. She noted the distinct differences in the life of women in Colombia as compared to the United States. She explains her experience back home. "The woman is very hard for us. For the men, no... the father, brothers, uncles, including husbands think the women have to serve them. So I want to change this idea for my children". In her new life, she notices, "You see the women in the United States thinks the espouse have the same roles; care for the children, cooking, work, you see?” She discusses the transformation from one life form to another as a metaphor for the change she has experienced as a woman. Comparing her own experiences to those of important books in her life was a means by which literacy supported her as an immigrant and a woman.

Another important finding of the study recognizes the diversity of Latino families: Immigrant families in a particular community demonstrate a wide and varied range of literacy practices that illustrate the importance of recognizing the heterogeneous nature of this group. Simply by noting the countries of origin of the students, it can be noted that they represent a variety of locales around the world. The five families in this study represent four different countries. Their educational backgrounds varied greatly as did the literacy practices in which they chose to engage. This fact should offer a word of caution to those who may assume that all Latino immigrants fit neatly in one category and highlights the importance of creating space in the curricula to learn about students as individuals.

One way in which to learn about individuals reflects another finding of the study: Home visits are a powerful practice that provide opportunities to greatly influence the life of a school. A primary finding of this study relates to the tremendous impact visits to children's homes have on the school community. This influence may be viewed as threefold in the sense that the simple yet uncommon act of visiting the home of a student powerfully affects the lives of the teachers, families, and students who participate. Before this study, the researcher believed 
that home visits would be a critical component for schools such as this one and yet, the magnitude of the ways in which all three parts of this triangle were affected by this experience was unexpected. The power of this is shown in several ways. For the parents, the experience of relating a variety of aspects of their lives during visits proved to be a deeply moving and important experience. For the students, the visits have paved a path for a deeper understanding of them as learners and, have yielded instructional strategies in the school that will serve to scaffold their learning. For the teachers, the sharing of this data has caused many to participate in the initiatives discussed here, and in one case, it inspired a teacher to conduct her own home visits.

One way the researcher has forged deeper understandings has been through acknowledging the ways in which families are fractured by the experience of immigration. The separation of families can be described as a "long, painful and disorienting ordeal” (C. Suarez-Orozco \& M. Suarez-Orozco, 2001, p. 66). For the Sanchez and Cortez families, signs of this ordeal were evident. Jose, whose father lived in the Dominican Republic, chose to write about their separation in his family history project when he was in class. With the help of his mother he wrote, "My father lives in the Dominican Republic, but I hope in God that we'll stay together soon”. This occurred during what could easily have been labeled Jose's "silent period” (D. Freeman \& Y. S. Freeman, 1994, p. 86), for he rarely talked in school. Of the five families in the study, four had to contend with extended periods of separation from spouses or children, a product of immigration that often goes unnoticed in school.

Many factors contribute to the painful separation of families. The difficulty in attaining visas is certainly a common complaint yet all of the families focused on conditions in their beloved home countries that caused them to flee, regardless of the legal ramifications. A common example was the extreme poverty that exists under corrupt governments. Marlene sighed as she told, "Too hard, our country” to explain her family's decision to come to the United States. She spoke of their financial struggles. At the time of their departure, for example, 25,000 sucres in Ecuador was equal to one U.S. dollar. The monthly earnings of the family were about $\$ 150.00$ in the United States, through their hard work they have been able to purchase their own home. Despite their achievements, Pedro often speaks of returning to Ecuador. Their legal status makes a trip home impossible and has imposed a cruel form of exile from their family, but Marlene has come to a realization that Pedro can not face, "We are good here. We don't know if we are good there".

\section{Reading for the World to Change}

Working more closely with the teachers, it became obvious that literacy lessons alone would not be sufficient for children coping with some of the difficult challenges they must face. In the school, poverty, homelessness, and the extraordinary conditions that can be a result of immigration are common concerns. For this reason, a non profit organization called "Reading for the World to Change" was organized. The title, inspired by the popular John Mayer song "Waiting on the World to Change" reflects the spirit of the project. The idea that reading is an act that has the power to bring about change is a message that is directed to both staff and students through the different initiatives of the project. Some of these initiatives include: (1) a mentoring program and (2) a fund raising event that included school-wide-read-a-thons and rummage sales that address issues spanning from the financial support of seriously ill children in the school and summer reading programs. These projects, though different in their scope, are intended to help to address the physical, emotional and academic needs of the children in the community. 
With the help of the teachers, the author has also established a mentoring program to address the problem of homework help for immigrant children. In the role as a facilitator, she challenged the teachers to consider the lives of the families. She shared stories of the hard working and dedicated parents that she had met as a result of the study. Through these conversations, teachers acknowledged the difficulty experienced by many parents, particularly those who do not speak English, in helping their own children with homework. A mentoring program has been for the last several years. At the end of the last school year, 24 members of the staff had mentored 34 of the students. There were also two events held for those involved, (1) a "Buddy Breakfast" and (2) a "Buddy Barbecue”. In addition to the practical help this program provides, mentoring has created another means by which the particular circumstances of the students are approached in a way that respects and strives to understand each individual.

\section{Creating Space for an Internally Persuasive Discourse}

Through observation and documentation of the everyday literacies of the families in this study, it was noted that literacies emerged as a means of contending with and navigating through the circumstances of life as an immigrant in a new country. These literacies however, could not be described as new. They are a combination of literacies in which each person previously engaged and carried into another existence and possess a transnational quality. This transformation is not unlike Bakhtin's (1981) concept of an "internally persuasive discourse” where "the internally persuasive word is half and half someone else's" (p. 345). For those who have chosen to live the life of an immigrant in a new country, the internally persuasive word may be seen as half from their life of an immigrant and half from their life in their new surroundings. But it is not only that, it is also half the voice of familiar cultural patterns and ways of being as a resource to be tapped, and half the new experiences associated with life as an immigrant which must be incorporated into different ways of understanding the world.

These may be viewed as transnational literacy practices in two separate but related ways. First, there is the practice of engaging in the familiar literacy events that are connected to home, (for example, reading periodicals, sharing recipes, and watching television programs). Second, there are ways of engaging in literacy that are transformed by the experience of immigration. These include the writing of poetry and the interpretation of works of literature. This type of interaction is dynamic in nature for "the semantic structure of an internally persuasive discourse is not finite, it is open; in each of the new contexts that dialogize it, and this discourse is able to reveal ever new ways to mean” (Bakhtin, 1981, p. 346). Considering literacy in this way recognizes the impact immigration has on the forms and functions of reading and writing in everyday contexts.

During this study, it became clear that all children need to have the opportunity to engage in an internally persuasive discourse in school as well. As an educator in her own classroom, this was an integral part of the author's pedagogy but approaching this concept as a professional staff developer/facilitator seemed a greater challenge. It occurred to her that as a learning community, the school should explore the topic of immigration through a school-wide reading of the Eve Bunting (1990) story, How Many Days to America? A Thanksgiving Story. This modern-day tale of a family leaving their Caribbean island home by boat under the cloak of night depicts this perilous journey and provides the opportunity to consider the Thanksgiving celebration from multiple perspectives. All the children in the school were encouraged to make connections to the story and then to respond in writing. Campano (2007) refers to writing of this nature as "acts of agency" (p. 60) and explains, "writing as 
agency does more than just reflect their worlds: It is also pragmatic, transforming the world, at least the world of the classroom, if only modestly” (p. 60). A fourth grade student named Jose responded to the Eve Bunting story through this powerful account of his own journey.

The story How Many Days to America reminded (me) of when I traveled in a boat to get to an island. I remember a man telling me to sit quietly and still. I remember the water splashing inside the boat and on me. I could not wait to reach the USA. The journey I took was horrible. It was long and lonesome. I could not wait to see my parents. It's a journey that I won’t forget. (Bunting, 1990, p. 9)

Those who heard Jose read these words will not forget either. Jose shared this reflection during a presentation for families of what is simply called Friendship Feast. The room was still as he read. The response in the room that day is a testament to the ways in which literacy may serve as a tool to support individuals through the difficult experience of immigration and the power of finding avenues to connect curriculum to the lives of students.

\section{Conclusion-Transforming the Work}

In reflection on the influence of ethnographic research on the work the author has done at the school, she is able to see the ways, (both obvious and subtle), that seeds of change have begun to take root. Her position as a professional staff developer/facilitator at the school has provided many opportunities to share the findings with a community of teachers and to put into motion its implications. The role of a facilitator/coach is uniquely suited to this type of work. A facilitator/coach works along side teachers as they puzzle through the questions that are presented daily. In these moments, the guidance provided is of critical importance.

In one example of this dynamic, a second-year teacher was pursuing her Master's degree. She wanted to discuss ideas for a topic for her thesis. Her initial idea was to develop a plan to guide parents as they helped their children with homework, specifically reading. The experiences of visiting families as part of the study and the impact this had on the author was shared. Together, a new topic was crafted, one in which this teacher decided to survey the parents of the children in her class through home visits to determine their perceptions of literacy and document the ways in which each family handled homework and reading practice with their children. During that semester, Carmen often spoke about her thesis and her decision to visit several parents in her class to conduct interviews. When she spoke of the experience of being in the homes of her students, Carmen proclaimed, "It changes everything!"

Carmen's declaration expressed a belief regarding this practice that has been learned through this ethnographic study; that is crossing the border between home and school does change everything and creates an alternate space that inhabits both domains. It is not unlike the transnational literacy practices of the families-a hybrid form of former and newer ways of being in school. It is in this space that educators may inform and thereby transform the schools in which they teach.

\section{References}

Agar, M. (1996). The professional stranger. San Diego: Academic Press.

August, D., \& Shanahan, T. (2006). Developing literacy in second-language learners: Report of the national literacy panel on language-minority children and youth. Mahwah, NJ.: Lawrence Erlbaum.

Bakhtin, M. M. (1981). The dialogic imagination (C. Emerson \& M. Holquist, Trans.). Austin, Texas: University of Texas Press. 
Berlak, H. (2001). Race and the achievement gap. Rethinking Schools, 15(4), 12-21.

Bunting, E. (1990). How many days to America?: A thanksgiving story. New York: Clarion Books.

Campano, G. (2007). Immigrant students and literacy: Reading, writing and remembering. New York: Teachers College Press.

Edwards, V. (Ed.). (2006). Diplomas count: An essential guide to graduation and policy rates. Special issues, Education Week, 25(41), 4-17.

Fix, M., \& Passel, J. (2003). U.S. immigration: Trends \& implications for schools. Presentation for the National Association for Bilingual Education, NCLB Implementation Institute, Albany, New York.

Freeman, D., \& Freeman, Y. S. (1994). Between worlds: Access to second language acquisition. Portsmouth, NH: Heinemann.

Freire, P. (1970). Pedagogy of the oppressed. New York: Continuum.

Glendon, M. A. (2006). Principled immigration. First Things, (June/July), 23-26.

Gonzalez, N., Moll, L., \& Amanti, C. (2005). Funds of knowledge: Theorizing practices in households, communities, and classrooms. Mahwah, New Jersey: Lawrence Erlbaum Associates, Publishers.

Hook, J. (2006). Poverty grows among children of immigrants in the U.S. Retrieved from www.migrationinformation.org /USFocus/display.cfm?ID=188

Nieto, S. (1996). Affirming diversity: The sociopolitical context of multicultural education. Boston, Massachusetts: Longman Publishers.

No Child Left Behind Act of 2001, Public Law 107-110, 107th Congress (January 8, 2002).

Romberg, R. (1996). Saints in the Barrio: Shifting, hybrid, and bicultural practices in a Puerto Rican community. Multicultural Review, 5(2), 16-25.

Suarez-Orozco, C., \& Suarez-Orozco, M. (2010). Children of immigration. Cambridge: Harvard University Press.

Suarez-Orozco, C., Todorova, I., \& Louie, J. (2002). Making up for lost time: The experience of separation and reunification among immigrant families. Family Process, 4(4), 625-643.

Weinstein, R. S. (2002). Reaching higher: The power of expectations in schooling. Cambridge: Harvard University Press. 